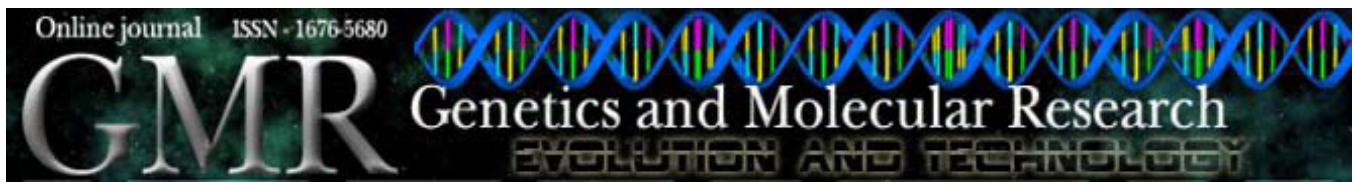

\title{
Bee communities (Hymenoptera: Anthophila) of the "Cerrado" ecosystem in São Paulo State, Brazil
}

\author{
S.R. Andena ${ }^{1}$, F.S. Nascimento ${ }^{2}$, P.C. Bispo ${ }^{3}$, M.R. Mechi', \\ S. Mateus ${ }^{1}$ and L.R. Bego ${ }^{1}$ \\ ${ }^{1}$ Departamento de Biologia, Faculdade de Filosofia, \\ Ciências e Letras de Ribeirão Preto, Universidade de São Paulo, \\ Ribeirão Preto, SP, Brasil \\ ${ }^{2}$ Departamento de Biologia, Laboratório de Entomologia, \\ Centro de Ciências Biológicas e da Saúde, \\ Universidade Federal de Sergipe, \\ Campus Universitário "Prof. José Aloísio de Campos", \\ São Cristóvão, SE, Brasil \\ ${ }^{3}$ Departamento de Ciências Biológicas, \\ Faculdade de Ciências e Letras de Assis, \\ Universidade Estadual Paulista, Assis, SP, Brasil \\ Corresponding author: S.E. Andena \\ E-mail: sergioricardoandena@gmail.com; sandena@usp.br
}

Genet. Mol. Res. 8 (2): 766-774 (2009)

Received December 12, 2008

Accepted January 26, 2009

Published July 7, 2009

\begin{abstract}
Five surveys of the bee communities in four "Cerrado" ecosystem reserves in São Paulo State were compared for species richness and similarity. These areas are fragment vegetation reserves located in the Cerrado Corumbataí Reserve (Corumbataí), Jataí Ecological Park (Luiz Antônio), Cajuru (Cajuru), and Vassununga State Park - "Gleba de Cerrado de Pé-de-Gigante" (Santa Rita do Passa Quatro). The methodology consisted of capturing bees foraging on flowers along transects, though with small differences be-
\end{abstract}


tween surveys. These "cerrado" areas have a large number of species of native bees, which are important pollinators in several Brazilian ecosystems. The community of bees varied among these different fragments. Based on 500 individuals (standardized by rarefaction), Cajuru, Corumbataí 1 and Corumbataí 2 were the areas with highest species richness, and Jataí and Pé-de-Gigante had the lowest species richness in the bee communities. The bee faunas of Corumbataí 2 and Pé-de-Gigante had the highest similarity, forming a group with the bee fauna of Cajuru. The bee faunas of Corumbataí 1 and Jataí were isolated from this group. We found that the bee species richness and similarity found in these "cerrado" areas cannot be explained by general factors such as the size of the fragment, the species richness of plants and the distance between the areas. Therefore, we suppose that local factors that differ among areas, such as interactions between populations, and competition and interference from surrounding areas influence and determine bee species richness and similarity in these reserves.

Key words: Hymenoptera; Anthophila; "Cerrado"; Community ecology

\section{INTRODUCTION}

The bees (Hymenoptera: Anthophila) are considered to be the most diverse group within the Hymenoptera (Neff and Simpson, 1993). The exact number of species of Anthophila is uncertain, but according to Michener (2000) there are about 30,000 species of bees in the world. However, this number could be higher (Roubik, 1989). Among insects, bees are commonly known as the most abundant group of flower visitors, and because of their extremely high dependence on floral resources throughout their life histories, they are good candidates as links between pollinator diversity and floral diversity (Michener, 1974).

In Brazil, the first extensive studies on bee communities were carried out at the beginning of the last century, mainly by Cockerell (1900) and Ducke (1906). However, a standardized methodology to measure the biodiversity of bees was only applied decades later by Sakagami et al. (1967). Since then this methodology has been applied in many surveys in several Brazilian ecosystems, such as urban areas (Laroca et al., 1982; Camargo and Mazucato, 1984; Knoll, 1985, 1990; Taura, 1990; Sofia, 1996), cattle pastures (Orth, 1983; Ortolan, 1989; Hoffmann, 1990; Silveira et al., 1993), caatinga (Martins, 1990; Castro, 1994; Aguiar, 1995; Aguiar and Martins, 1997), high altitude fields (Faria and Camargo, 1996), and Atlantic Rain Forest, comprising dunes, sand plains and coastal hills (Zanella, 1991; Wilms, 1995; Aguilar, 1998; Alves-dos-Santos, 1996, 1999). In most Brazilian ecosystems, the family with the highest number of species has invariably been the Apidae, with about $50 \%$ the total number of species, followed by the Halictidae (about 25\%), the Megachilidae (about 12\%), and the Andrenidae and Colletidae (about 7 and 6\%, respectively) of all collected species (Pinheiro-Machado et al., 2002).

On a broad geographic scale, bee species richness is believed to be higher in temperate warm xeric or warm mesic habitats rather than in the floristically more complex moist tropics 
(Michener, 1979, 2000). In fact, bee diversity is higher in the temperate zone than in the tropics. Therefore, a simple link between bee diversity and plant diversity is unlikely, given the high floristic diversity found in many tropical habitats (Gentry, 1983).

The Brazilian savanna, or "cerrado", comprises about $22 \%$ of the Brazilian territorial area with more than two million $\mathrm{km}^{2}$. This ecosystem presents a wide flora variety, in which about $80 \%$ of species are either primarily or secondarily pollinated by bees (Silberbauer-Gottsberger and Gottsberger, 1988). The high degree of dependence on floral resources is reflected by numerous adaptive modifications of the bees' floral diet (Thorp, 1979).

In the "cerrado", intensive bee surveys have been conducted by Campos (1989), Silveira (1989), Pedro (1992), Silveira and Campos (1995), Coelho-Carvalho and Bego (1995, 1996, 1997), Mateus (1998), and Andena et al. (2005). However, additional data on both fauna and flora diversity are needed because this ecosystem is increasingly threatened and reduced by human activities.

The degradation, destruction and fragmentation of habitats are the principle reason of the current increase in extinction rates. Other contributing factors are over-exploration, introduction of species from other regions, pollution, extensive agriculture, global warming, and cumulative effects of human interference with the environment. The same forces that result in extinctions cause a series of other adverse effects that are precursors to extinction, including extirpation of local species, loss of genetic diversity within species, and disruption of food webs or communities.

Knowledge of the bee fauna diversity in the "cerrado" in São Paulo State remains fragmentary (Pedro and Camargo, 1999), in part because most studies remain either unpublished or unavailable (Pinheiro-Machado et al., 2002). In an attempt to increase the availability and usefulness of such information, we examined the richness and similarity of the data available on the bee communities in this ecosystem.

\section{MATERIAL AND METHODS}

\section{The surveys}

This study was carried out in three areas located in the "cerrado" of the northeast region of São Paulo State. These areas comprised: i) Corumbataí Reserve in Corumbataí (Corumbataí 2, 2000-2001; Andena et al., 2005); ii) Jataí Ecological Station in Luiz Antônio (1991-1993; Mateus, 1998), and iii) Vassununga State Park (Gleba de Cerrado de Pé-de-Gigante) in Santa Rita do Passa Quatro (2000-2001). These areas were compared with data from Corumbataí (Corumbataí 1, 1982-1985) (Campos, 1989; Silveira and Campos, 1995) and from Cajuru (1988-1989) (Pedro, 1992; Pedro and Camargo, 1999). All these areas are fragments of native vegetation, ranging from latitudes $21^{\circ} 36^{\prime} \mathrm{S}$ to $22^{\circ} 18^{\prime} \mathrm{S}$ and longitudes $47^{\circ} 12^{\prime} \mathrm{W}$ to $47^{\circ} 42^{\prime} \mathrm{W}$. The altitude of the areas ranged from 600 to $900 \mathrm{~m}$. The methodology consisted of collecting bees, which were foraging on flowers with entomological nets along transects that had been demarcated in the respective areas (Sakagami et al., 1967).

The bee specimens were deposited in the collection of the Departamento de Ecologia, Instituto de Biociências-UNESP, Rio Claro, SP (Corumbataí 1), Setor de Ecologia FFCLRPUSP, Ribeirão Preto, SP (Corumbataí 2, Luis Antônio and Pé-de-Gigante), and the collection of J.M.F. de Camargo, FFCLRP-USP, Ribeirão Preto, SP (Cajuru). 


\section{Analyses}

Richness was evaluated with rarefaction curves (Hurlbert, 1971; Simberloff, 1972), using the Monte Carlo permutation method. To estimate the number of taxa for $\mathrm{k}$ individuals, $\mathrm{k}$ individuals were randomly withdrawn from a sample and the observed number of taxa was recorded. That procedure was repeated 1000 times. The procedures were undertaken using the Ecosim 5 simulation program (Gotelli and Entsminger, 2000).

The data matrix was used to calculate a similarity matrix among the samples (Q mode) using the Morisita-Horn index (Horn, 1966; Krebs, 1998). Visualization of that similarity matrix was obtained through an agglomerative cluster analysis (Romesburg, 1990). UPGMA was used to obtain the dendrogram (Krebs, 1998). Dendrogram distortion was evaluated by the cophenetic correlation index (Romesburg, 1990). That index was obtained correlating the original similarity matrix with the matrix obtained from the dendrogram; $r \geq 0.8$ is considered to be a good value (Rohlf, 2000). The effect of geographic distance on faunistic similarity was tested with the Mantel test, using 5000 permutations (Manly, 1994; Legendre and Legendre, 1998). The cluster analysis and the Mantel test were ran with the NTSYS 2.1 program (Rohlf, 2000). Though numerous specimens of Apis mellifera were collected, this species was not considered in our analysis.

\section{RESULTS AND DISCUSSION}

\section{Bee richness of different areas of "cerrado" in São Paulo State}

The various studies that we included were carried out by different researchers. Comparative analysis of bee fauna among different areas, in most cases, is difficult due to several reasons: 1) collection variability (number of collectors, total period of collection, collector's ability); 2) size of sampled area; 3) floral diversity; 4) floral characteristics (density, phenology, color, size, and height); 5) influence of surrounding areas. However, some conclusions can be made from these data to provide a comprehensive notion of the bee diversity in this region and habitat.

Richness is an important characteristic to describe communities. This characteristic may be influenced by several factors on distinct scales. Among these factors are: 1) regional factors, such as biogeografic patterns and geographic barriers, and 2) local factors, such as interactions among species, heterogeneity of environment, etc. Additional care must be taken when the aim of the work is comparison of the richness between distinct communities. Therefore, a standardized method for collecting is always desirable. Due to these problems, we evaluated richness using rarefaction curves. This resolved part of the problem, because the comparison was made for the same number of individuals.

The surveys carried out in the "cerrado" of São Paulo State showed a number of bee species ranging from 74 (Pé-de-Gigante) to 193 (Cajuru), with the number of individuals collected ranging from 653 (Corumbataí 1) to 3433 (Cajuru). The results for 500 individuals (standardized by rarefaction) showed that Cajuru, Corumbataí 1 and Corumbataí 2 were the areas with the highest richness, and the areas of Jataí and Pé-de-Gigante had the lowest richness in bee communities (Figure 1). There was no significant relation between standardized richness and the sampling effort (Spearman $\mathrm{r}=0.56 ; \mathrm{P}=0.32$ ). 

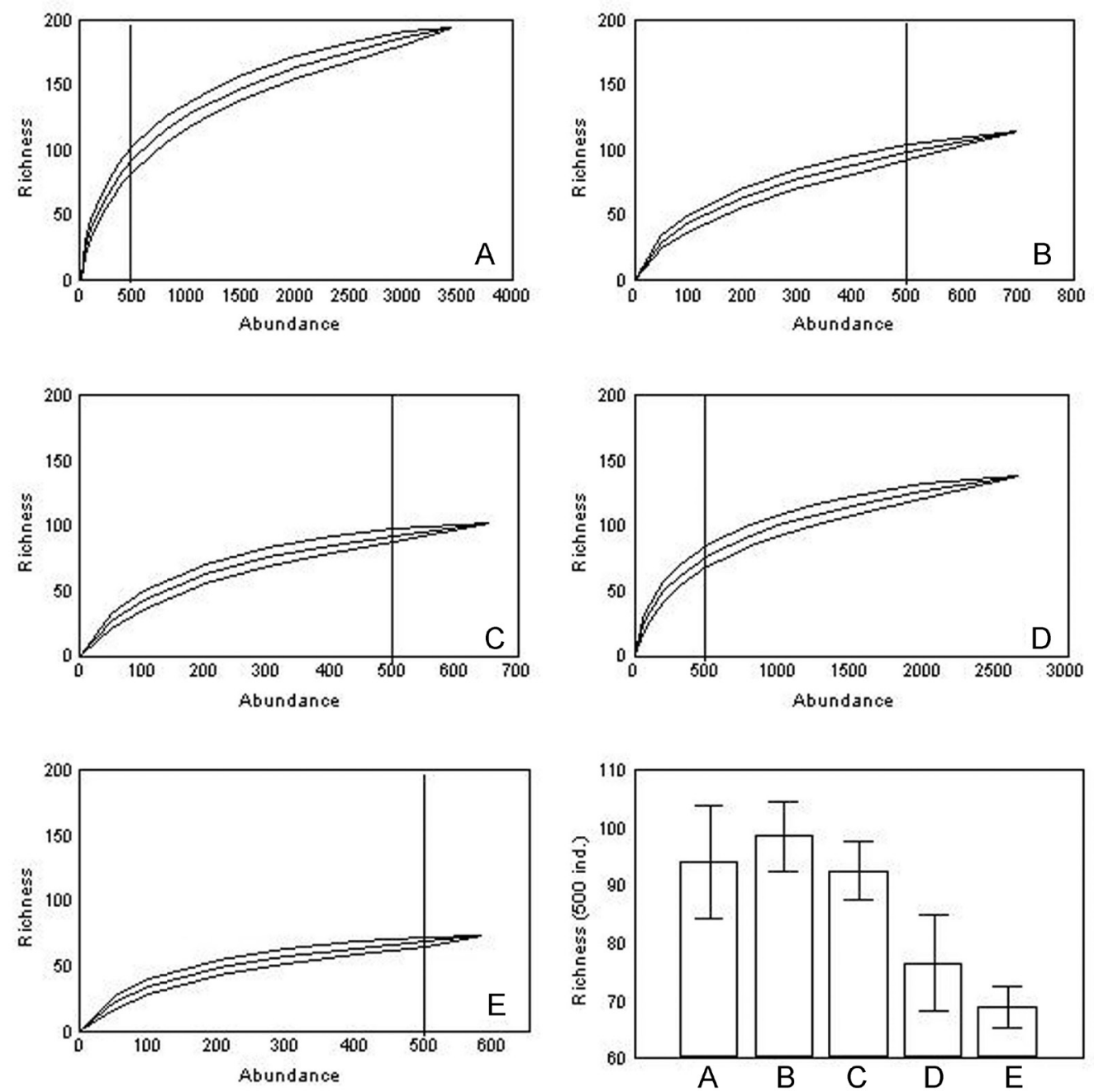

Figure 1. Rarefaction curves of bee communities collected in "cerrado" areas of São Paulo State. Confidence interval at 95\%. A. Cajuru; B. Corumbataí 1; C. Corumbataí 2; D. Jataí; E. Pé-de-Gigante.

A positive correlation between species richness and the size of the area has frequently been reported in various communities. This is especially important given the fragmentation of natural ecosystems, as is the case in São Paulo State, where only small fragments of "cerrado" exist. The relation between the richness and the size of the area may be explained by several factors: 1) greater heterogeneity of habitats, which occurs more frequently in large areas; 2) random colonization from a pool of species, which also is more probable in large areas, and 3 ) the extinction rates, which are higher in smaller areas. However, we did not find a significant relationship between richness and fragment size (Spearman $\mathrm{r}=0.36 ; \mathrm{P}=0.55)$. 
Environmental heterogeneity is another important factor that has frequently been associated with species richness. Greater heterogeneity may indicate more available niches, which allows a higher number of species to live in the same area. In the case of bees, species richness in visited plants may be an important indication of the heterogeneity of resources. Hence, we expected the richness in plant species visited by bees to be positively correlated with the richness in bee species. We did not confirm this assumption since there was not a significant correlation between species richness in bees and plants (Spearman $\mathrm{r} \approx 0 ; \mathrm{P} \approx 1$ ).

We found that the bee richness in the different "cerrado" areas cannot be explained by general factors, such as the size of the fragmented area and the richness of plants. Therefore, we suppose that local factors that differ among areas, such as interactions between populations, competition and interference from surrounding areas may influence and determine bee species richness in these areas.

\section{Similarities among the bee fauna of different areas of "cerrado" in São Paulo State}

The community of bees varied among the different areas of "cerrado" in São Paulo State. The bee fauna of Corumbataí 2 and Pé-de-Gigante showed the highest similarity, forming a group with the bees of Cajuru. The bees of Corumbataí 1 and Jataí were isolated from the first group (Figure 2). The faunistic similarity among the different communities may be attributed to both environmental and habitat similarities, despite the distances between them. Close areas may have the same regional pool of species; also, there may be a contagious distribution of species among the areas. Therefore, a relationship between area proximity and faunistic relatedness should be expected. However, the distance between areas was not the most important component because geographic distance did not correlate with fauna similarity (Mantel test, $\mathrm{r}=-0.174 ; \mathrm{P}$ $=0.309$ for 5000 permutations). These study areas were close to each other. Given the strong relationship between bee fauna and plants, a relationship between floral similarity and similarity among bee communities is to be expected. However, we did not test this hypothesis in our study because not all data on flora composition were available.

Our analysis demonstrated severe changes in the faunistic composition in the area of Corumbataí over the years (Figure 2). We had expected a higher similarity between the two surveys in the same area. But, surprisingly, the interval of 16 years resulted in a faunistic substitution in this area. This fact might be explained by the substitution of vegetation in the surrounding areas. When Campos (1989) carried out her studies in that area, only some fragments of natural vegetation and small areas of cattle pasture were found in the area. In 2000 , the vegetation of the surrounding area had been mainly substituted with a sugar-cane monoculture, and the areas of cattle pastures had considerably increased (Andena et al., 2005). Two theories help to elucidate the substitution of the bee fauna along the 16 years between the surveys: 1) the bees that used to built their nests in the surrounding area and that possibly were visitors in the Corumbataí area may have vanished, or 2) the bees that lived in the surrounding area may have moved to the Corumbataí area, leading to a competition with the original fauna. Unfortunately, the exact cause for the faunistic changes remains obscure due to the long gap of 16 years between the two surveys (Andena et al., 2005).

Bees play an important role in the maintenance of ecosystems, especially as regards pollination (Silberbauer-Gottsberger and Gottsberger, 1988). Consequently, the isolation of populations, as well as the loss of nesting sites and of food resources can result in a reduction 
in bee diversity (Silveira, 1989; Sofia, 1996). We suggest continued comparative surveys of bee diversity, to provide a way to quantify the influence of fragmentation on faunistic composition and species richness.

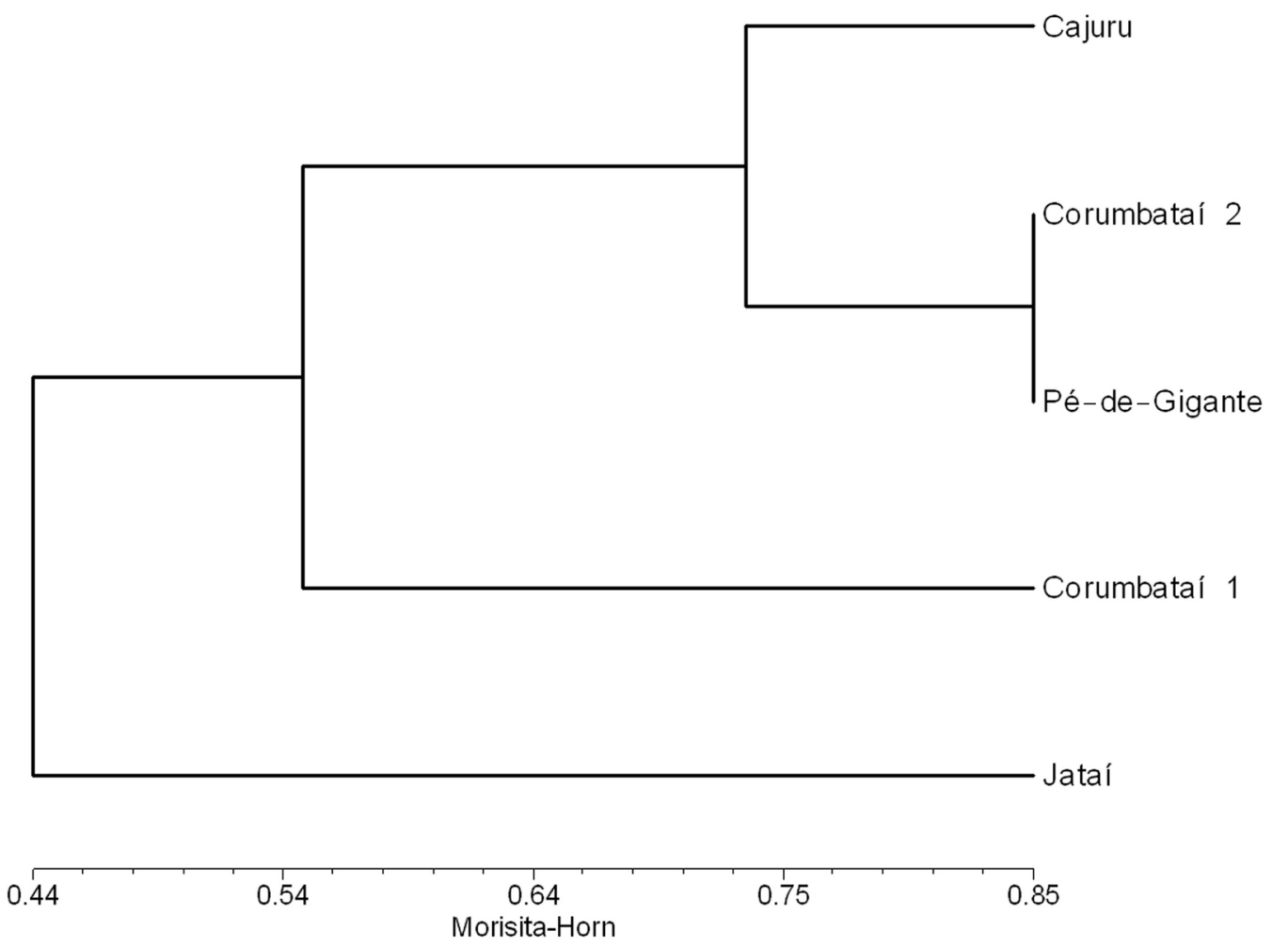

Figure 2. Dendrogram obtained by UPGMA, representing the similarity of bee communities collected in "cerrado" areas of São Paulo State. Cophenetic correlation index (0.84).

\section{ACKNOWLEDGMENTS}

The authors thank FAPESP (Fundação de Amparo à Pesquisa do Estado de São Paulo) for financial support (\#00/06405-2). S.R. Andena and P.C. Bispo thank CNPq for fellowships. We also are grateful to Profs. Drs. Sebastião Laroca (UFPR) for identification of species, and Maria J.O. Campos (UNESP) for facilities during our visit in Rio Claro Herbarium, and Mr. Edílson S.R. Silva for fieldwork assistance.

\section{REFERENCES}

Aguiar CML (1995). Abundância, Diversidade e Fenologia de Abelhas (Hymenoptera, Apoidea) da Caatinga (São João do Cariri, PB) e sua Interações com a Flora Apícola. Master’s thesis, Universidade Federal da Paraíba, João Pessoa. Aguiar CML and Martins CF (1997). Abundância relativa, diversidade e fenologia de abelhas (Hymenoptera, Apoidea) na 
caatinga, São João do Cariri, Paraíba, Brasil. Iheringia, Ser. Zool. 83: 151-163.

Aguilar JBV (1998). A Comunidade de Abelhas (Hymenoptera: Apoidea) da Reserva Florestal de Morro Grande, Cotia, São Paulo. Doctoral thesis, Instituto de Biociências da Universidade de São Paulo, São Paulo.

Alves-dos-Santos I (1996). Bienen und Mellitophie Bluetenpflanzen in der Kuerstenregionung im Atlantischen Regenwalg von Rio Grande do Sul (Brasilien), mit Einer Fallstudie zu Lanngzungenbienen und Tristylen Wasserhyazinthen. Doctoral thesis, Universität Tuebingen, Tuebingen.

Alves-dos-Santos I (1999). Distribuição vertical de uma comunidade de abelhas (Hymenoptera, Apoidea) do Rio Grande do Sul. Rev. Bras. Entomol. 43: 225-228.

Andena SE, Bego LR and Mechi MR (2005). A comunidade de abelhas (Hymenoptera, Apoidea) de uma área de cerrado (Corumbataí, SP) e suas visitas às flores. Rev. Bras. Zoocienc. 7: 55-91.

Camargo JMF and Mazucato M (1984). Inventário da apifauna apícola de Ribeirão Preto, SP, Brasil. Dusenia 14: 55-87.

Campos MJO (1989). Estudo das Interações entre Comunidade de Apoidea, na Procura de Recursos Alimentares, e a Vegetação de Cerrado da Reserva de Corumbataí-SP. Doctoral thesis, Universidade Federal de São Carlos, São Carlos.

Castro MS (1994). Composição, Fenologia e Visita às Flores pelas Espécies de Apidae em um Ecossistema da Caatinga (Casa Nova-9 $9^{\circ} 5^{\prime}$ S/ 41 ${ }^{\circ} 50^{\prime}$ W). Master's thesis, Instituto de Biociências, Universidade de São Paulo, São Paulo.

Cockerell TDA (1900). Descriptions of new bees collected by H.H. Smith in Brazil. Proc. Acad. Nat. Sci. Phila. 52: 336337.

Coelho-Carvalho AM and Bego LR (1995). Seasonality of dominant species of bees in the Panga Ecological Reserve, Cerrado, Uberlândia, MG. An. Soc. Entomol. Bras. 24: 329-337.

Coelho-Carvalho AM and Bego LR (1996). Studies on Apoidea fauna of cerrado vegetation at the Panga Ecological Reserve, Uberlândia, MG, Brazil. Rev. Bras. Entomol. 40: 147-156.

Coelho-Carvalho AM and Bego LR (1997). Exploitation of available resources by bee fauna (Apoidea-Hymenoptera) in the Reserva Ecológica do Panga, Uberlândia, State of Minas Gerais, Brazil. Rev. Bras. Ent. 41: 101-107.

Ducke A (1906). Neue Beobachtungen über die Bienen der Amasonslander. Allg. Z. Entomol. 5: 51-60.

Faria GM and Camargo JMF (1996). A Flora Meliófita e a Fauna de Apoidea de um Ecossistema de Campos Rupestres, Serra do Cipó-MG, Brasil. In: Anais do II Encontro Sobre Abelhas, Ribeirão Preto, 228.

Gentry AH (1983). Dispersal ecology and diversity in Neotropical forest communities. Sonderb. Naturwiss. Ver. Hamburg 7: 303-314.

Gotelli NJ and Entsminger GL (2000). EcoSim: Null Models Software for Ecology. Version 5.0. Acquired Intelligence Inc. and Kesey-Bear. Available at [http://homepages.together.net/ gentsmin/ecosim.htm]. Accessed July 2007.

Hoffmann M (1990). Estrutura e Importância de uma Comunidade de Abelhas (Hymenoptera: Apoidea) no Rio Grande do Sul, para a Polinização de Plantas Cultivadas. Doctoral thesis, Universidade Federal do Paraná, Curitiba.

Horn HS (1966). Measurement of "overlap" in comparative ecological studies. Am. Nat. 100: 419-424.

Hurlbert SH (1971). The nonconcept of species diversity: a critique and alternative parameters. Ecology 52: 577-586.

Knoll FRN (1985). Abundância Relativa das Abelhas no Campus da Universidade de São Paulo com Especial Referência à Tetragonisca Angustula Latreille. Master's thesis, Universidade de São Paulo, São Paulo.

Knoll FRN (1990). Abundância Relativa, Sazonalidade e Preferências Florais de Apidae (Hymenoptera) em uma Área Urbana. Doctoral thesis, Universidade de São Paulo, São Paulo.

Krebs CJ (1998). Ecological Methodology. Benjamin Cummings, New York.

Laroca S, Cure JR and Bortoli C (1982). A associação das abelhas silvestres (Hymenoptera, Apoidea) em uma área restrita no interior da cidade de Curitiba (Brasil): uma abordagem biocenótica. Dusenia 13: 93-117.

Legendre P and Legendre L (1998). Numerical Ecology: Developments in Environmental Modelling. Elsevier Science, Amsterdam.

Manly BFG (1994). A Primer of Multivariate Statistics. Chapmam and Hall, London.

Martins CF (1990). Estrutura da Comunidade de Abelhas (Hym., Apidae) na Caatinga (Casa Nova, BA) e na Chapada Diamantina (Lençóis, BA). Doctoral thesis, Universidade de São Paulo, São Paulo.

Mateus S (1998). Abundância Relativa, Fenologia e Visita as Flores pelos Apoidea do Cerrado da Estação Ecológica de Jataí, Luis Antônio-SP. Master's thesis, Universidade de São Paulo, Ribeirão Preto.

Michener CD (1974). The Social Behavior of the Bees. A Comparative Study. Belknap Press of Harvard University, Cambridge.

Michener CD (1979). Biogeography of the bees. Ann. Mo. Bot. Gard. 66: 277-347.

Michener CD (2000). The Bees of the World. Johns Hopkins University Press, Baltimore.

Neff L and Simpson BB (1993). Bees, Pollination Systems and Plant Diversity. In: Hymenoptera and Biodiversity (LaSalle $\mathrm{J}$ and Gauld ID, eds.). CAB International, Wallingford, 142-167.

Orth AI (1983). Estudo Ecológico de Abelhas Silvestres (Hymenoptera, Apoidea) em Caçador, SC, com Ênfase em Polinizadores 
Potenciais de Macieira Pirus malus L. (Rosaceae). Master’s thesis, Universidade Federal do Paraná, Curitiba.

Ortolan SNLS (1989). Biocenótica em Apoidea (Hymenoptera) de Áreas de Cultivo de Macieira (Pirus malus) em Lages, Santa Catarina, com Notas Comparativas e Experimento Preliminar de Polinização com Plebeia emerina F. Master's thesis, Universidade Federal do Paraná, Curitiba.

Pedro SRM (1992). Sobre as Abelhas (Hymenoptra, Apoidea) em um Ecosistema de Cerrado (Cajuru, NE do Estado de São Paulo): Composição, Fenologia e Visita às Flores. Master's thesis, Universidade de São Paulo, Ribeirão Preto.

Pedro SRM and Camargo JMF (1999). Apoidea Apiformes. In: Joly CA and Bicudo CEM (Org). Biodiversidade do Estado de São Paulo, Brasil: Síntese do Conhecimento ao Final do Século XX, 5: Invertebrados Terrestres. Brandão CRF andCancello EM (eds.). São Paulo, FAPESP, 193-211.

Pinheiro-Machado CA, Alves-dos-Santos I, Silveira FA, Kleinert AMP, et al. (2002). Brazilian Bee Surveys: State of Knowledge, Conservation and Sustainable Use. In: Pollinating Bees: a Conservation Link Between Agriculture and Nature (Kevan P and Imperatriz-Fonseca VL, eds.). Ministry of Environment, Brasília, 115-129.

Rohlf FJ (2000). NTSYS 2.1: Numerical Taxonomic and Multivariate Analysis System. Exeter Software, New York.

Romesburg HC (1984). Cluster Analysis for Researchers. Lifetime Learning, Belmont.

Roubik DW (1989). Ecology and Natural History of Tropical Bees. Cambridge University Press, New York.

Sakagami SF, Laroca S and Moure JS (1967). Wild bee biocenotics in São José dos Pinhais (Pr), South Brazil. Preliminary report. J. Fac. Sci. Hokkaido Univ. 6: 57-127.

Silberbauer-Gottsberger I and Gottsberger G (1988). A polinização de plantas do cerrado. Rev. Bras. Biol. 48: 651-663.

Silveira FA (1989). Abelhas silvestres (Hymenoptera: Apoidea) e suas fontes de alimento no Cerrado da Estação Florestal de Experimentação de Paraopeba - Minas Gerais. Master's thesis, Universidade Federal de Viçosa, Viçosa.

Silveira FA and Campos MJO (1995). A melissofauna de Corumbataí (SP) e Paraopeba (MG) e uma análise da biogeografia das abelhas do cerrado brasileiro (Hymenoptera, Apoidea). Rev. Bras. Entomol. 39: 371-401.

Silveira FA, Rocha LB, Cure JR and Oliveira JF (1993). Abelhas silvestres (Hymenoptera, Apoidea) da Zona da Mata de Minas Gerais. II. Diversidade, abundância e fontes de alimento em uma pastagem abandonada em Ponte Nova. Rev. Bras. Entomol. 37: 595-610.

Simberloff D (1972). Properties of the rarefaction diversity measurement. Am. Nat. 106: 414-418.

Sofia SH (1996). As Abelhas e suas Visitas às Flores em Duas Áreas Urbanas. Doctoral thesis, Universidade Estadual Paulista, Rio Claro.

Taura HM (1990). A Comunidade de Abelhas Silvestres (Apoidea) do Passeio Público, Curitiba, PR, Sul do Brasil: uma Abordagem Comparativa. Master's thesis, Universidade Federal do Paraná, Curitiba.

Thorp RW (1979). Structural, behavioral, and physiological adaptations of bees (Apoidea) for collecting pollen. Ann. Mo. Bot. Gard. 66: 788-812.

Wilms W (1995). Die Bienenfauna im Küstenregenwald Brasiliens und ihre Beziehungen zu Blütenpflanzen: Fallstudie Boracéia, São Paulo. Doctoral thesis, Eberhard-Karls-Universität Tübingen, Fakultät für Biologie, Tübingen.

Zanela FVC (1991). Estrutura da Comunidade de Abelhas Silvestres (Hymenoptera, Apoidea) da Ilha do Mel, Planície Litorânea Paranaense, Sul do Brasil, com Notas Comparativas. Master's thesis, Universidade Federal do Paraná, Curitiba. 